\title{
ELECTORAL VIOLENCE AND YOUNG PARTY CADRES IN ZAMBIA
}

\author{
Kabale Ignatius Mukunto \\ Kabale Ignatius Mukunto is a lecturer at the \\ Dag Hammarskjöld Institute for Peace and Conflict Studies, \\ Copperbelt University, Kitwe, Zambia
}

\begin{abstract}
Zambia's 2016 general elections were a turning point in the country's political history, with electoral violence threatening its democratic fabric. This paper analyses accounts of electoral campaigns by one private online newspaper, the Lusaka Times, to reflect on the relationship between electoral violence and young party cadres. Evidence from the study indicates that negative socioeconomic conditions, leadership manipulation and incentives as well as the perception of plural politics all contribute to the susceptibility of young people to electoral violence. The violence witnessed in 2016 included molestation and intimidation, seizure of public property, public disorder, vandalising of party property, lawlessness and aggressive rhetoric. The paper also notes that events of 2016 were counterweight to the consolidation of democracy as the activities of young party cadres undermined the free political participation of other stakeholders.
\end{abstract}

Keywords: electoral violence, electoral campaigns, young party cadres, Zambia

\section{INTRODUCTION}

Ascent to power through an election is assumed to legitimise those in government. Elections are considered a neutral arbiter for the contending parties and to some extent instil confidence in political players. Conversely, voters see considerable incentive in being part of the process to usher in their preferred candidates to facilitate improved service delivery. Elections constitute a transitional mechanism at the core of democracy, ideally supporting all institutions. Yet, if the behaviour of participants in this process is not regulated, attendant returns such as peace and security are imperilled. In spite of a seemingly peaceful record of elections, Zambia's last two elections (in the presidential by-election of January 2015 and 
the general elections of August 2016) present an ugly trend of election-related violence. The rank and file of major political parties - their political cadres - are now frequently implicated in election-related violence. The behaviour of these young men and women in recent elections has led to attention-grabbing headlines in both print and electronic media. Some of these accounts question the value of their participation in the country's democratic institutions and political culture.

Consistent with these concerns, Omotola (2010) notes that electoral violence is a major source of democratic instability with substantial threats of deconsolidation. Thus, the trend not only poses a threat to the sustainability of a country's democratisation process but also jeopardises future political culture. This paper is motivated by the fact that Zambia's past two elections have been characterised by an emerging trend of violence that peaked during the campaigns and the immediate post-election period. This tendency presents a troubling departure from previous elections that witnessed less pre- and post-electionrelated violence.

The paper draws on empirical evidence from Zambia's political events in 2016 to explain the relationship between electoral violence and members of the political party youth league, including pertinent questions that merit critical consideration. For instance, why are young political party members drivers of electoral violence? What form does electoral violence take? What bearing has electoral violence on the consolidation of democracy? But first, it is essential to have an appreciation of what constitute electoral violence.

\section{UNDERSTANDING ELECTORAL VIOLENCE}

Within the realm of peace and conflict studies there is an intrinsic connection between conflict and violence and to understand electoral violence it is necessary to explain political conflict. Political conflicts are defined as being driven by the need to alter political, economic or cultural structures (Barber 2013, p. 338). Consistent with this, political violence is a development of political conflicts which those seeking change seldom avoid. Thus, political violence is explained as the use of force by a group with a political purpose or motivation or influenced by political matters. It encompasses but is not limited to violence against civilians or political rivals as well as violent demonstrations (Paalo 2017).

Electoral violence is in turn an offshoot of political violence, defined by its timing and intent. Adolfo, Kovacs, Nyström and Utas (2012, p. 2) argue that electoral violence is a forced and premeditated approach employed by both incumbent and opposition political actors propelled by the attainment of specific objectives associated with electoral competition. The occurrence of electoral violence is not restricted to physical confrontation but includes other aggressive 
tactics including threats of violence, harassment and intimidation. Based on the motivation of its perpetrators, electoral violence can be divided into different classes.

Burchard (2015) for example, categorises this sort of violence into 'incidental and strategic'. She argues that incidental electoral violence ensues as an outgrowth of protest and electoral events prior to or just after an election when tensions are high and opposing parties are still in close proximity. Strategic electoral violence, on the other hand, is premeditated and engaged in for a multiplicity of reasons, one being to influence the outcome of an election.

In addition, electoral violence may be neatly compartmentalised into three integral aspects: the point at which it takes place; the perpetrators and victims involved; and the form it takes. For instance, Birch and Muchlinski make the following distinction:

... between violence that happens before, during and after the month in which the election occurs, violence perpetrated by state, non-state, and international actors, and violence that causes actual physical harm, or is instead employed to coerce, restrict, or otherwise influence electoral processes through methods that fall short of physical force.

(Birch \& Muchlinski 2017, p. 4)

Other sources identify both structural and institutional factors as triggers of electoral violence. For instance, Adolfo et al. (2012), cite 'informal patronage systems and exclusionary politics as well as the uncertainties associated with losing political power among other aspects responsible for electoral violence'. Institutional sources, they claim, is manifest in 'failed or flawed elections, election fraud and weak or manipulated institutions or institutional rules' that direct the electoral process. However, there are occasions with autonomous institutions when, as Fjelde and Hoglund claim (2014, p. 301), prospects of electoral defeat should not be sufficient to drive politicians to participate in violent electoral tactics.

Although electoral violence is characterised by an array of strategies that different political players use at stages of the electoral cycle, some see it more broadly. Fjelde and Hoglund (2014, p. 307) argue that electoral violence should be identified by issue(s) in addition to timing. They assert that while electoral violence can occur at any time in the course of an electoral cycle, there may be candidate intimidation during primaries which would occur before electoral campaigning and voting.

In terms of its effects, electoral violence accounts for protracted incumbent legitimacy crises, socioeconomic turbulence, the risk of armed uprising, a culture of impunity for the perpetrators, population displacement and humanitarian 
emergencies, and a loss of confidence in the electoral process, including impending effective political competition and participation (Adolfo et al. 2012; Leonard 2010; Omotola 2010). Participation is particularly significant given its bearing on the political life of the youth, discussed in the following section.

\section{ELECTORAL VIOLENCE AND THE YOUTH}

The extent of young political party cadres' involvement in political violence stretches from a mere exchange of insults between different political groups, to relaying intelligence information. For example, a study of political youth leagues in Burundi revealed that the youth had tasks such as mobilising followers, collecting money and relaying intelligence (Berckmoes 2015). However, political violence is at its height during elections. This period illuminates both the indispensability of political youth wings and the full extent of their thuggery with acts that include snatching ballot boxes, voter and opponent intimidation, breaking up opposition rallies, and seizing the voter cards of perceived opponents (Okafor 2017; Paalo, 2017). In addition, political violence among the youth is characterised as a practice whereby political leaders manipulate and mobilise young people to perform violent acts in order to realise and further their own political objectives (Umar 2016, p. 147).

The prevalence of this violence is seen as one of the hallmarks of Africa's political landscape; in Africa, political violence is perpetrated at ground level by the youth. In the view of Okafor $(2017$, p. 2), 'this appears in the form of political thuggery which has been seen as criminalization of politics'. Okafor defines political violence in Africa as taking different forms in different areas in the quest to lure youths into such conduct, either as hired thugs or as party members.

In addition, in the pre-election period the political activities of young people may be associated with 'unlawful seizure and control over facilities of public good such as bus terminals and markets to seek rents for themselves and the political elite' (Paalo 2017, p.7). Paalo further claims that they also exhibit what is known as 'destructive engagements' such as vandalising public property; rioting and violent protests, seizure and control of public property. These and many other expressions of political conflict and violence are driven by a myriad of factors, three of which merit discussion.

First, the unfavourable socioeconomic conditions of young people including unemployment, poverty, lack of good education and institutional structures, and a lack of access to modern facilities (Akpan 2015). Due to high levels of poverty, unemployment and general deprivation, young people are vulnerable to what Akpan describes as the recruitment and arming by bourgeois politicians to serve as political thugs and assistants during elections. This section of society remains 
a principal factor in a country's stability before and after election periods when left to the whims of political party expediency. Forti and Maina (2012) note that there are dangers in ignoring and marginalising youth constituencies, especially in situations with weak societal institutions and infrastructure. Based on their reflections about Kenyan youths, Forti and Maina stress that the precarious situation of many young people is exacerbated by their weak socioeconomic status. Herein lies their vulnerability to manipulation and exploitation.

Second, political leadership and its related aspects are said to be responsible for young people's inclination to act violently. For instance, in West Africa the concept of Godfatherism is relatively common. Godfathers, according to Akpan (2015, p. 152) are influential politicians who command respect in public because of their material possessions, wealth and charisma. Akpan adds that their actions range from arming their boys who in turn snatch ballot boxes, to killing and maiming where their actions are obstructed. Further, others claim that Godfathers remain a factor in the perpetuation of political violence through their financial support of young people (Okafor 2017, p. 2).

Third, young people's appetite for political violence is driven by their perception of plural politics and the application of violence. Researchers and observers of young peoples' participation in political violence argue that many youths do not understand the meaning of multiparty politics. Their rudimentary appreciation is instead dictated by their political masters who arm them to kill and maim when the election pendulum swings against the former. It is these acts that contribute to the normalisation of violence among some young people. Political elites invariably recruit marginalised young people and socialise them in these 'norms' of violence in order to maintain existing power structures, notes Umar (2016).

In sum, marginalisation of young people from mainstream politics and their restriction to the fringes of the democratic processes generates a lasting effect. This, according to Okafor (2017, p. 3) is counterweight to democratic development as it continues to undermine the essence of democracy in Africa. Zambia, with its fledgling democratic system, warrants an appraisal of its young political players and the contribution of its cadres in shaping its development.

\section{YOUNG PARTY CADRES IN ZAMBIA}

From the time of Zambia's independence in 1964 and its first republic under the ruling political party, the United National Independence Party (UNIP), youth leagues in particular have greatly influenced the political outlook. Their functions and responsibilities were then to serve as guardians of moral standards by intervening in any aspect of community affairs (Chiluba 1995; Scott 1976). Beyond 
community matters, they were also at the helm of what Phiri (2001) called an oppressive card-checking campaign. Men and women without UNIP cards were denied access to markets, shops or public transport to and from work, while under UNIP's one-party state rule the UNIP youth members were considered above the law, claims Phiri.

As members of UNIP's youth league, some party stalwarts were allegedly involved in attacking and burning the houses of those perceived as belonging to the opposition. While Zambia's transition from one-party state to multiparty democratic dispensation has been described as 'free of violence' and a 'masssupported pact', there are some outliers that merit mention (Erdmann \& Simutanyi 2003). For example, observers of the 1991 general elections shared some of the pre-election violent incidences, as follows:

...upon arrival at a soccer match in July, Kaunda and his entourage were pelted by fans throwing stones, bottles and fruit. At the home of Dipak Patel, a prominent Lusaka businessman running for parliament on the MMD ticket, unknown assailant severely beat a security guard and destroyed two vehicles. In Eastern Province, a UNIP stronghold, there were frequent reports that huts and granaries of MMD sympathisers were being burned to the ground...Youths from both parties intimidated those attending rallies of their opponents.

(National Democratic Institute for International Affairs; The Carter Center 1992, p. 45)

Despite the adoption of a multi-party parliamentary democracy in 1991, the negative influence of political party youth league members continues unabated in the country's third republic. For example, there was continued meddling in grassroots structures such as village and ward development committees under the guise of 'decentralisation of power' (Sichone 1996) witnessed during the UNIP era. This had been a dominant feature of the Movement for Multi-party Democracy (MMD). At the start of their party's third mandate, young party cadres under the MMD administration had become fully immersed in political and electoral violence and were allegedly involved in beating and harassing journalists from both private and public media organisations. They were also involved in harassing and intimidating political opponents, voters and the general citizenry. A case in point is the manhandling of Mr. Hakainde Hichilema, UPND President during the filing of nominations for the Chilanga by-elections in Lusaka Province in 2010. Next, an MMD youth chair threated the gang rape of FDD leader, Ms. Edith Nawakwi, for her critical stance against the MMD. Third, MMD cadres were also at the helm of violent confrontations, clashes and skirmishes with cadres from opposition parties PF and UPND during electoral campaigns. 
Some of the clashes between the PF and MMD in Lusaka revolved around restricting the access to market stores and other public spaces. Market places and bus stations became the centres for clashes between different political parties, to the point where one party would claim oversight of one station, and the other party another. This oversight, noted by Hansen (2010), extended to different cadres and factions unlawfully collecting or soliciting levies.

Thus, the trend of violent youth wings, synonymous with the former ruling MMD, has now spread to today's major political parties including the current ruling Patriotic Front (PF) and the opposition United Party for National Development (UPND). Their youth sections invariably remain indispensable for electoral canvasses. In what Bwalya (2017, p. 1554) describes as fiercely competitive electoral campaigns that have characterised Zambia's nascent multiparty political terrain, these youth cadres are a regular feature.

While young party stalwarts from the PF and UPND have risen to positions of eminence by perpetuating electoral violence, this does not apply to smaller parties. Because of their structures and membership, few of these smaller political parties that contested the nationwide presidency and parliamentary seats in 2016 seem to have had belligerent youth leagues, that is young party cohorts willing and able to engage violently with their opponents as obtains in PF, UPND and MMD. However, the country's ugliest acts of election-related violence took place during the 2016 elections, as discussed below.

\section{METHODOLOGY}

An event catalogue of occurrences of election-related violence in 2016 reinforces this reflection (see Figure 1). The initial premise is that since the 2011 elections, Zambia has witnessed unprecedented high levels of political intolerance and hostilities among political players, civil society organisations and sections of the media (Yezi Consulting and Associates 2013; Zambia Election Information Centre 2016). This reached a peak during the 2016 elections as violent incidents escalated the tension between political parties as well as between their respective supporters. The study split these events into five categories adapted from the qualitative study of party youth activists and low-intensity electoral violence in Ghana by Bob-Milliar (2014, p. 136).

- First, molestation and violent intimidation; these comprised alleged abduction, physical assault of political opponents using offensive weapons such as clubs, machetes, stones or petrol bombs.

- Second, seizure of public/state property and occupancy; these include incidences such as impounding the property of the electoral management body, including vehicles, polling materials (both ballot boxes and allegedly marked or unmarked ballot papers), and holding government staff hostage. 
- Third, protests and public disorder; these became commonplace occurrences in expressing political dissent. They include arson attacks, malicious damage to or setting private and public property alight, stoning private and public vehicles, blocking roads, and clashing with police as well as harassing journalists.

- Fourth, party property vandalising; another familiar and unpleasant albeit isolated practice in previous elections (2001, 2006, 2008, 2011 and 2015); this entails pulling down or defacing opponent's party campaign materials, attacking campaign vehicles, and damaging party offices.

- Finally, hate speech or violent rhetoric was an unprecedented occurrence and included verbal retaliation or threats, name-calling and insults, and offensive public statements.

For empirical evidence, the study analysed stories of electoral campaigns by one private online news platform, Lusaka Times. This news outlet has a balanced coverage of both ruling and opposition political party activities, including the events that took place between January and December 2016.

\section{RESEARCH FINDINGS}

The study revealed that throughout 2016 young political cadres from both the incumbent Patriotic Front (PF) and the leading opposition party, United Party for National Development (UPND) were active participants in political and electionrelated violence. In some incidences, as shown later in this paper, more senior leadership has also actively participated. In terms of actual political occurrences, most of these incidents in 2016 consisted of protests and public disorder, followed by molestation and violent intimidation. Peak months ran from May to August, prior to polling day and immediately after the announcement of election results (see Table 1).

The study revealed that several acts of violence by political party cadres were retaliatory. An impending attack by PF cadres on UPND offices thwarted by police in Lusaka's Rhodes Park area in May 2016, for example, was an act of retaliation. The previous day, altercations between PF and UPND cadres in Matero Township culminated in 'malicious damage and ransacking of the former's constituency offices'. The UPND, however, claimed they were provoked by PF cadres carrying pangas, machetes and axes who disrupted their youth assembly in the area (Lusaka Times, 9 May, 2016).

What is evident from this study is that the violent nature of young political party cadres evinces itself in some degree of lawlessness. For example, following the court appearance of their vice president for administration, UPND cadres mounted an unlawful procession blocking traffic in and out of Kitwe. 
Table 1: Cases of Election-Related Violence in Zambia 2016

\begin{tabular}{|l|c|c|c|c|c|c|}
\hline \multicolumn{7}{|c}{ Categories of Event Catalogue of Election Related Occurrences } \\
\hline Month & $\begin{array}{c}\text { Molestation/ } \\
\text { Violent } \\
\text { Intimidation }\end{array}$ & $\begin{array}{c}\text { Seizure Public/ } \\
\text { Private Property/ } \\
\text { Occupation }\end{array}$ & $\begin{array}{c}\text { Protests/ } \\
\text { Public } \\
\text { Disorder }\end{array}$ & $\begin{array}{c}\text { Party } \\
\text { Property } \\
\text { Vandalism }\end{array}$ & $\begin{array}{c}\text { Hate Speech } \\
\text { Violent } \\
\text { Rhetoric }\end{array}$ & TOTAL \\
\hline January & 3 & 3 & 3 & 2 & 2 & 13 \\
\hline February & 3 & 1 & 2 & 1 & 2 & 9 \\
\hline March & 2 & - & 3 & - & 4 & 9 \\
\hline April & 2 & - & - & 2 & 2 & 6 \\
\hline May & 4 & 1 & 4 & 2 & 3 & 14 \\
\hline June & 5 & - & 8 & 5 & 1 & 19 \\
\hline July & 2 & - & 4 & 2 & 1 & 9 \\
\hline August & 2 & 3 & 11 & 1 & - & 16 \\
\hline September & 1 & - & - & - & - & 1 \\
\hline October & 1 & - & 1 & - & - & 2 \\
\hline November & - & - & - & - & - & - \\
\hline December & - & - & - & - & - & - \\
\hline Total & 25 & 8 & 36 & 15 & 15 & 99 \\
\hline
\end{tabular}

Source: Compiled by author, 2018

As young party members from the UPND escorted their leader, a state police officer overseeing a checkpoint near the host hotel was beaten up. Similarly, in June 2016, UPND and PF members clashed following a supposedly peace-oriented engagement, a conflict management meeting at the Civic Centre in Mazabuka, Southern Province. The damage to the vehicles parked at the Civic Centre and injuries sustained of those shot by armed cadres was symptomatic of the cadres' sheer disregard of the law (Lusaka Times, 29 June 2016). The public disorder that characterised violent actions by young political cadres was in several instances preceded by public gatherings and/or rallies.

Further violence perpetuated during electoral campaigns was in some cases spontaneous and without justification. In the Kanyama compound of Lusaka, for example, during one of their campaigns UPND cadres ran amok damaging the front windscreens and sliding doors of five private minibuses parked at the local bus station (Lusaka Times, 27 July 2016). This public disorder prompted by young political party members affected journalists from both public and private media 
outlets, to the point of displeasing media heads like Richard Mwanza, Director General of the Zambia National Broadcasting Corporation (ZNBC). He threatened to switch off the cameras if political cadres continued with their unacceptable behaviour of harassing their reporters (Lusaka Times, 7 June 2016).

From a review of stories covered by the Lusaka Times, it was also clear that molestation and violent intimidation of political opponents was not confined to urban regions. In Muchinga Province, Shiwang'andu area, PF cadres attacked a UPND campaign team with sticks and stones, disrupting scheduled meetings. In retaliation, a group of youths in UPND attire damaged vehicles and property belonging to those suspected of being PF supporters in Lusaka's Northmead shopping area. The youth party cadres claimed their attacks were in revenge for the attack on their leaders in Shiwang'andu (Lusaka Times, 16 June 2016).

In the town of Monze, Southern Province, police prevented a PF youth mobilisation rally from being disrupted by UPND cadres, arresting two. In Namwala district in the same province, a female parliamentary candidate from the Forum for Democracy and Development (FDD), was brutally attacked by UPND cadres. In his reaction to this incident, FDD spokesperson Antonio Mwanza alleged that the attack was led by UPND's immediate past and aspiring candidate together with her team, extensively damaging the FDD candidate's vehicle and attempting to set it ablaze (Lusaka Times, 19 June 2016).

Later, in an apparent disagreement with the call by PF President Edgar Lungu for the country to hold a day of national prayer to end the political violence, Mwanza and the FDD media staff demanded introspection. They argued there was need to question who arms cadres with guns, pangas, military fatigue, money and beer (that is, whether it is God or politicians). Even though the Namwala incident was allegedly perpetrated by UPND cadres, Mwanza directed his demands to the $\mathrm{PF}$ and the government, querying, 'who was abetting and tolerating violence'? (Lusaka Times, 15 July 2016). Interestingly, Antonio Mwanza subsequently crossed over to the Patriotic Front where he is currently (2019) the deputy media director. This illustrates the argument by Bwalya and Sichone (2016) that defectors include ordinary members as well as former office bearers who move to join dominant or ruling parties.

As noted earlier, one of the significant occurrences prior to the 2016 elections was the impounding of the Electoral Commission of Zambia (ECZ) properties. This was at the height of the campaigns (see Figure 1).

Party cadres from the opposition UPND seized ECZ trucks in three different cities on suspicion of carrying pre-marked ballot papers. First was in Livingstone city, Southern Province, where UPND members impounded, damaged and searched eight new ECZ trucks. Second, the ECZ truck broke down in Senanga 
District, Western Province providing an opportunity for UPND cadres in the area to impound the truck on allegations that it had pre-marked ballot papers. In Kabwe, Central Province, cadres from the same party blocked the road, intercepted and impounded three ECZ trucks, and again similar allegations were advanced. Despite the searches of all these ECZ trucks (which yielded nothing) and the exercise monitored by officers from the Zambia Police, UPND cadres still seemed sceptical. They accompanied trucks from Livingstone to Lusaka as well as Kabwe to Mkushi alongside the police. The accompaniment was premised on ensuring that nothing was put in the trucks along the way. Some party officials justified their actions as 'praise-worthy alertness' (Lusaka Times, 7 August, 2016).

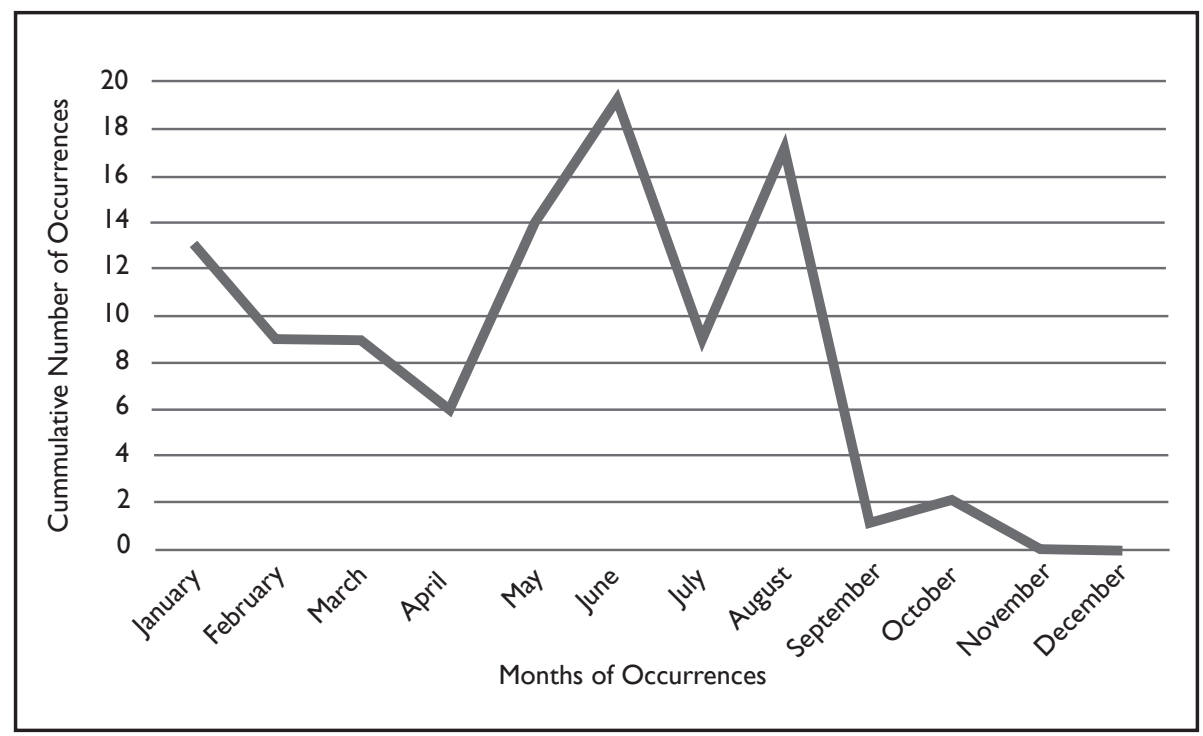

Source: Compiled from Lusaka Times, 2018

Figure 1: Cases of Election-Related Violence in Zambia - 2016

Party property vandalising is another incident-type that characterised the 2016 election campaigns. From accounts in the Lusaka Times, both PF and UPND party cadres participated in this sort of violence which included defacing and/ or pulling down billboards, and damaging offices and motor vehicles. As noted earlier, violent acts by political party cadres were in some cases retaliatory, and vandalising party property was no exception. Barely weeks after the UPND Chairperson for Elections, Ackson Sejani, vowed to protect their billboards from being vandalised by PF cadres, he had UPND cadres arrested for the same act. Addressing the media, he warned the PF to stop provoking his party beyond 
human patience, and that their preventive actions to protect their billboards should not be condemned. A month later, five UPND cadres in Lusaka's Cairo Road were arrested for defacing and removing PF bill boards and posters (Lusaka Times, 4 July, 2016).

Furthermore, the euphoria that characterised the filing of presidential nominations by PF presidential candidate Edgar Lungu in June 2016, culminated in damage to the UPND secretariat. Hordes of PF cadres violently attacked and damaged property belonging to UPND supporters. Acknowledging that nomination filing is cause for celebration, UPND Secretary-General Stephen Katuka, said it should not be an excuse for violence, abuse and intimidation (Lusaka Times, 2 June 2016). While he implored the police to arrest those that committed criminal acts regardless of political affiliation, his party's cadres in Livingstone were ambushing and stoning a PF campaign vehicle. The attack left two PF officials injured, one of them a former UPND member.

Unlike Mwanza, whose defection to the PF had no reprisals from the FDD, one of the victims in the Livingstone attack associated the incident with his defection. He lamented that, 'it is unfortunate that UPND is targeting its former members who have exercised their democratic right of joining the PF...' (Lusaka Times, 24 June 2016). While this incident may not have had the blessing of senior party officials within UPND, leaders from both PF and UPND are guilty of hate speech and violent rhetoric. For example, during a radio interview in a private local station the PF national youth chairperson, Steven Kampyongo, described leaders from the UPND as terrorists. This was in response to earlier remarks attributed to some senior UPND leaders who had appeared on the same platform previously and allegedly promised to break Kampyongo's lips (Lusaka Times, 17 June, 2016).

However, what is noteworthy from this exchange regarding the current discourse is the vaunt about the chairperson's support from youth members. He retorted that he was not threatened by the UPND leadership as he was youth chairperson in the PF and commanded the largest following of youth in the country. Whether this translates to having more young people at his disposal or the capacity to exert more violence against political opponents is unclear. However, comments from senior political leaders inadvertently encouraged young party cadres to see violence as the norm. For example Mumbi Phiri, PF Deputy Secretary-General, defended attacks on UPND supporters in the Sinda District of Eastern Province, by stating that 'political provocation' enraged the PF cadres (Lusaka Times, 28 January, 2016). Incensed by attacks on his party by PF cadres, including the Shiwang'andu incident mentioned earlier, UPND Vice President, Geoffrey Bwalya Mwamba, instructed youths from his party to 'hit back' whenever attacked by PF cadres. 


\section{DISCUSSION}

While Zambia's record cannot equal the scale of electoral violence elsewhere in Africa, as Bekoe (2010) and Burchard (2015) observe, the recurrent trend since 2011 is worrisome. Conflict and difference are inevitable aspects of every human society and Zambia's growing democracy is no exception. However, how these differences are handled may serve to engender political and particularly electoral violence. Of particular interest within the polity is the indispensable role of young political party cadres in driving electoral violence. It is evident from this study that at least four explanations can be advanced as motivation for their participation in electoral violence.

First, the association of young party cadres with either political or electoral violence has tangible roots in the country's second republic and one-party state (1973-1990). UNIP stalwarts and members of the youth league extended their mandate to include taking care of any 'dissenting voices'. Sadly, this entailed using militaristic and violent means. Agarwal (2012) aptly notes that each generation partly inherits attitudes and beliefs towards politics from earlier generations, and that these attitudes and values are partly a reaction to on-going (contemporary) politics. Thus, successive ruling parties have included young party stalwarts with aggressive and belligerent approaches, albeit to different degrees. From UNIP's successor the MMD, to the PF, including the opposition UPND, youth leagues see themselves as front-line disciplinarians.

Second, some senior party leaders bluntly acknowledge inflaming violence, while others couch their incitement in an oblique fashion. One example is that of a leader of a prominent political party during the 2018 campaign for the Chilanga constituency by-elections in Lusaka Province. He reportedly expressed his gratitude to his youth cadres for defending themselves against what he described as 'PF thugs'. He further urged young party stalwarts to defend themselves whenever attacked. What is evident from this study is that leaders from both the PF and the UPND have openly incited young party cadres to use violence against their opponents. Such acts contribute to the normalising of violence among young people.

The third incentive for young party cadres' predisposition to electoral violence includes material benefits such as branded caps, T-shirts and wrappers. Bwalya (2017, p. 1559) considers these to be intricately woven into the fabric of electoral campaigns. Bwalya further posits that while this unique clientelist plan targets community groups, young party members are not left out. They too receive these clothing items. Not only are young people recipients of material goods but also of electoral campaign promises such as job creation. It is this lack of job opportunity that, claim Forti and Maina (2012, p. 76), leads to a cohort 
of idle and frustrated youth who constitute a likely target for recruitment into negative criminal or violent activities. Their pre-disposition to violent conduct during elections is aggravated by drug abuse which may or may not be facilitated by their sponsors. A study commissioned by the United Nations Development Programme (UNDP) as part of Election Cycle support in 2017, found that party cadres abuse both cannabis and alcohol. To some extent this drives them to engage in violence, particularly during elections (Namaiko \& Etyang, 2017) when they intimidate rival parties and voters in acts of hooliganism inimical to social and political norms.

Fourth, young party cadres' rudimentary understanding of multiparty democracy seems to be a factor in dealing with dissent. While senior party leaders do communicate civilly when faced with political differences, young party stalwarts are seldom courteous. Their take is that, as representatives of dominant political parties, they should always lead and/or win while others follow or lose. Findings of the European Union Election Observation Mission in 2016 revealed that smaller parties and independent candidates in the Copperbelt, Eastern, North-Western and Southern provinces faced intimidation from the larger PF and UPND (European Union, 2016). In addition, cadres from these two parties behaved as though no other party should be permitted to campaign in their respective strongholds. This echoes the violent counter and retaliatory attacks alluded to previously in Shiwang'andu constituency and Lusaka's Northmead areas by PF and UPND cadres respectively.

While the main focus of this paper has been on inter-party election-related battles, the PF is not immune to intra-party clashes. Following the demise of $\mathrm{Mr}$. Sata in 2014, the PF was once more immersed in internal party battles, particularly over who should stand as president in the January 2015 presidential by-elections. After an extended tussle between two distinct camps, one led by former Vice President Dr. Guy Scott and the other by Mr. Edgar Lungu, there was a churchbrokered reconciliation. The polarisation may have run deep, particularly among lower-level party members, but the presence of church leaders triggered a reunion process that gave the $\mathrm{PF}$ its presidential candidate.

Further, seemingly as a repeat of the dissatisfaction in 2011 over parliamentary adoptions in some Ndola constituencies, PF cadres did not welcome all the 2016 adoptions. For example, some cadres from Chimwemwe and Wusakile constituencies in Kitwe alleged that parliamentary candidates were imposed on them and they felt that leaders with grassroots support were left out. While senior leader's preferences led to low-level intra-party tensions, the final outcome was that independent candidates with popular support won both constituencies.

As evidenced from the findings, electoral violence takes several forms, notably physical attacks and intimidation. The occurrence of the latter is not restricted 
to pre-election or election periods but post-election too. For example, following the inauguration of PF President-elect Edgar Chagwa Lungu, a PF youth leader in Lusaka warned civil servants not to expect any salary increments as they did not support his party's re-election (Lusaka Times, 12 September, 2016). Such remarks against ordinary citizens and professional civil servants are not just an affront to basic human rights but an assault on the very essence of democracy, that is, an assault on the right of the people to vote for and thus elect representatives of their choice.

On the other hand, the destruction of property including vehicles and buildings raises questions of whether any line can be drawn between electoral violence and criminality, or whether perpetrators of these acts are in fact young people. There is a thin line between election-related violence and criminality, as some youth leagues are led by what could be termed 'youth claimants'. A study by Yezi Consulting and Associates (2013) observed that the chairpersons of the youth wings of three major political parties in Zambia are over 40 years old. Not only is this above the state's prescribed youth age range (15-35 years), but these supposed youth leaders invariably see violent acts as the norm. This begs the question of whether the real youth, that is those in the 15-35 year range, would consider refraining from using violence.

It may be that this aspect of age is not central as all political parties draw considerable strength from these young party stalwarts whose primary responsibility is broadening party influence. While some may function as foot soldiers and undertake genuine functions, 'noble roles' such as membership recruitment, the vast majority are guilty of perpetrating wrongs against their political opponents. This is why young party stalwarts are indispensable in political parties. Both incumbents and opposition parties need them and this study attests to their role in Zambia's political history. During political campaigns, gangs of both unarmed and armed young party cadres are behind the wheels of electoral violence.

Zambia's 2016 political campaigns also exhibited what appears to be a growing habit of hate speech or violent political rhetoric. Messages by often senior political leaders are couched in provocative and hateful language resulting in long-lasting violence by their rank and file. This violent rhetoric may not dissipate once the political battles have waned and the study by Namaiko and Etyang noted the increasing use of incendiary remarks by politicians. They report that these remarks, which often characterise political rallies and social media platforms, revolved around 'ethnicity and other falsehoods' (Namaiko \& Etyang, 2017, p. 26).

Another aspect evident from the study is the disregard of law and public order, in particular the provisions of the country's electoral code of conduct. This disregard of the law parallels the proclivity of party cadres to a militaristic outlook, a development that parties seem to tolerate. The conduct of these party 
cadres is reminiscent of UNIP's one-party state's militants who, according to Phiri (2001, p. 237) are 'a law onto themselves, no one dared to challenge them at least openly'. However, in the current democratic dispensation this behaviour should not be allowed to take hold. Permitting party cadres to remain unchallenged runs counter to the consolidation of democracy.

An example that may illustrate this dent on democracy, is the Lusaka mayoral by-election held in 2018. From a total of 839027 registered voters only 131777 (15.88\%) participated in the elections (Electoral Commission of Zambia 2018). Although the leading opposition party leader claimed that voter apathy was due to failure by the Electoral Commission of Zambia (ECZ) to run credible elections, others saw it differently. The low voter turnout was attributed to widespread electoral violence which resulted in over $80 \%$ of the voters staying home despite the election day being declared a holiday (Chali 2018).

As a consequence, Koko (2013) notes, election related violence undermines democratic institutions. It also diminishes the credibility of institutions (including political parties) responsible for entrenching democracy. The observations from Zambia's 2016 election campaigns point to the cultivation of a climate of fear perpetuated by young party cadres. This is described as a worrisome trend of violence and intimidation, endangering a secure environment for the democratic process and a hindrance to citizens - voters, political party supporters, and political candidates - participating in elections (The Carter Center 2016, p. 34).

\section{CONCLUSION}

The study identifies at least four main aspects of electoral violence. First, the nature and extent of electoral violence being witnessed today among Zambia's young party cadres may be the fruits of seed sown during UNIP's one-party state. The notoriety of UNIP's uniformed party militants and the aggressive behaviour against those with dissenting voices is being re-enacted today among young members from major political parties, notes Phiri (2001). Given the growing hooliganism, militancy and sheer disregard of the law during elections (in particular the electoral code of conduct) these party cadres are slowly becoming unaccountable to party discipline. From UNIP to MMD, nearly all political parties, including the $\mathrm{PF}$, are offshoots of the MMD. This means that some sort of umbrella youth league modus operandi needs to cover behaviour in all parties.

Second, the principal drivers of election-related violence are party cadres from the two leading political parties in Zambia, the PF and UPND. They are the front-runners in implementing electoral violence; their support makes some senior party members equally culpable. The expectation that these young party stalwarts should serve as conduits between their respective parties and the populace to disseminate party ideals and programmes, remains elusive. 
Third, violence committed by these party loyalists is both incidental and strategic, to use Burchard's (2015) categorisation. Often parties' public gatherings and/or rallies engendered public disorder and violent action, with each party on the lookout for the opposition's political events so that skirmishes were often premeditated. Conversely, the violence during vote canvassing was incidental, as indicated by some of the cases in this study. Incidental or strategic electoral violence as executed by young party cadres undermines the consolidation of a fledgling democracy such as Zambia's.

Given the intensity of violence during electoral campaigns, and the fatalities in some cases, the distinction between criminality and mere election-related clashes is obscured. The violence orchestrated by armed party cadres in 2018, during a parliamentary by-election in Lusaka Province, led some political stakeholders to express pessimism about Zambia's 2021 general elections (The Zambian Observer, 6 June, 2018). They fear that, if the current cohort of weaponwielding young party members are not restrained, there is a great propensity for attitudes to harden and trigger more troubles in future.

Fourth, the predisposition of young party cadres to election-related violence may perhaps be driven by their rudimentary understanding of pluralist politics. While most of their senior leaders may communicate in a civil fashion when faced with differences, young party cadres are seldom socialised to do the same. For the latter, political disagreements are synonymous with violence. In peacebuilding parlance, the claim is that the political socialisation of the current cohort of young people lacks peace-oriented mechanisms in dealing with or handling political dissent and conflicts.

Finally, as Zambia anticipates its next election in 2021, it is imperative that young party cadres are constructively engaged and drawn into the political life of the country. Failure to do so may result in violent political outbursts before, during and after the elections.

\section{---- REFERENCES}

Adolfo, EV, Kovacs, MS, Nyström, D \& Utas, M 2012, 'Electoral Violence in Africa', The Nordic Africa Institute Policy Notes, Issue 3, pp. 1-4.

Agarwal, RC 2012, Political theory: Principles of political science, S. Chand, New Delhi. Akpan, DA 2015, 'Appraisal of the role of political violence: The development of youths in Nigeria in the 21st Century', African Research Review, vol. 9, no. 3, pp. 147-156.

Barber, BK 2013, 'Political conflict and youth', The Psychologist, vol.26, no 5, pp. 336339.

Bekoe, D 2010, 'Trends in electoral violence in sub-Saharan Africa', USIP PeaceBrief, Issue 13, pp. 1-5. 
Berckmoes, LH 2015, 'Youth, politics and violence in Burundi: Gullible followers or tactics actors', In: FVS. a. VM Reyntiens, ed. L'Afrique des Grands Lacs: Annuaire 2014-2015, pp. 21-3.

Birch, S \& Muchlinski, D 2017, 'The Dataset of Countries at Risk of Electoral Violence', Terrorism and Political Violence, Volume DOI: 10.1080/09546553.2017.1364636, pp. 1-20.

Bob-Milliar, GM 2014, 'Party youth activists and low-intensity electoral violence in Ghana: A qualitative study of party foot soldiers' activism', African Studies Quarterly, vol. 15, no. 1, pp. 125-152.

Bosi, D \& Malthaner, S 2014, 'A Contentious Politics Approach to the Explanation of Radicalization', In: L Bosi, C Demetriou \& S Malthaner, eds. Dynamics of Political Violence: A Process-Oriented Perspective on Radicalisation and the Escalation of Political Conflicts, Ashgate, Farnham, pp. 1-23.

Burchard, SM 2015, Electoral violence in sub-Saharan Africa: Causes and Consequences, First Forum Press, Boulder Co.

Bwalya, J 2017, 'Unravelling clientelism in the Zambian electoral campaigns', Third World Quarterly, vol, 38, no.7, pp. 1551-1565.

Bwalya, J \& Sichone, O 2016, 'I Will Crawl Before You - Political endorsements, defections and patronage in Zambian elections', Africa Insight, vol. 46, no. 3, pp. 118-130.

Chali, R 2018, 'Only 15\% voted in Lusaka Mayoral elections', Lusaka Times, 30 July, pp. 1-3.

Chiluba, FTJ 1995, Democracy: The challenge of change, Multimedia, Lusaka.

Electoral Commission of Zambia, 2018. Electoral Commission of Zambia. [Online] Available at: http://ecz-news.com/news/official-results-of-the-26th-july2018-elections/[Accessed 9 September 2018].

Erdmann, G \& Simutanyi, N 2003, 'Transition in Zambia: The Hybridisation of the Third Republic', Konrad Adenauer Foundation, Occasional Papers, Issue December, pp. 1-97.

European Union, 2016. Final Report - Republic of Zambia: General Education and Referendum, Lusaka: European Union Election Observation Mission.

Fjelde, H \& Hoglund, K 2014, 'Electoral Institutions and Electoral Violence in SubSaharan Africa', British Journal of Political Science, Issue 46, pp. 297-320.

Forti, D \& Maina, G 2012, 'The danger of marginalisation: An analysis of Kenyan youth and their integration into political, socioeconomic life', ACCORD Monograph Series, Issue 1, pp. 55-85.

Hansen, KT 2010, 'Changing youth dynamics in Lusaka's informal economy in the context of economic liberalization', African Studies Quarterly, vol. 11, nos 2 \& 3, pp. 13-27.

International Institute for Democracy and Electoral Assistance 2015, 'Youth 
participation in electoral processes: new roles for African electoral management bodies', IDEA Policy Brief, Issue November, pp. 1- 4.

Koko, S 2013, 'Understanding Election Related Violence in Africa: Patterns, Causes, Consequences and a Framework for Preventive Action', Journal of African Elections, vol. 12, no. 33, pp. 51-88.

Leonard, DK 2010, 'Elections and conflict resolution in Africa', In: KT Matlosa, GM Khadiagala \& V Shale ed., When elephants fight: preventing and resolving election-related conflicts in Africa, EISA, Johannesburg.

Namaiko, T \& Etyang, O 2017, 'Conflict structural vulnerability assessment (SVA) Zambia' , United Nations Development Programme, Lusaka.

National Democratic Institute for International Affairs; The Carter Center 1992, The October 31, 1991, National Elections in Zambia, National Democratic Institute for International Affairs. Washington, D.C.

Okafor, S 2017, 'Youth involvement in political violence/thuggery: A counter weight to democratic development in Africa', Journal of Political Sciences and Public Affairs, vol. 5, nol. 3, pp. 1-4.

Omotola, S 2010, 'Explaining Electoral Violence in Africa's new Democracies', Journal of Conflict Resolution, vol. 10, no. 3, pp. 51-73.

Paalo, SA 2017, 'Political party youth wings and political violence in sub-Saharan Africa: A case of Ghana', International Journal of Peace and Development Studies, vol. 8, no. 1, pp. 1-14.

Phiri, BJ 2001, 'Colonial Legacy and the Role of Society in the Creation and Demise of Autocracy in Zambia, 1964-1991', Nordic Journal of African Studies, vol. 10, no. 2, pp. 224-244.

Scott, I 1976, 'Party functions and capabilities: The local level UNIP organization during the first republic (1964 -1974)', African Social Research, Issue 72, pp. $107-128$.

Sichone, OB 1996, 'The Problems of the State and Civil Society', In: OB Sichone \& B Chikulo, eds. Democracy in Zambia: Challenges for the Third Republic, Sapes Books, Harare.

The Carter Center 2016, The Carter Center's Experts Mission to the Zambian Presidential and Parliamentary Elections 2016 - Final Election Report, Carter Center, Lusaka.

Umar, BM 2016, 'Political Violence Amongst Youth Groups in Africa's Budding Democracies - An Explorative Studies of Concepts, Issues and Experiences', Research on Humanities and Social Sciences, vol. 6, no. 17, pp. 146-153.

Yezi Consulting and Associates 2013, Political governance study in Zambia, Diakonia Zambia, Lusaka.

Zambia Election Information Centre 2016, 2016 Pre-election citizens report, Zambia Election Information Centre, Lusaka. [Accessed 3 April 2018] 